\title{
The Apectodinium spp. acme as an evidence for the Paleocene-Eocene thermal maximum from the Polish Outer Carpathians
}

\author{
Danuta CYBULSKA ${ }^{1, *}$ and Jacek RUBINKIEWICZ ${ }^{2}$ \\ 1 University of Warsaw, Faculty of Geology, wirki i Wigury 93, 02-089 Warszawa, Poland \\ 2 Polish Geological Institute - National Research Institute, Rakowiecka 4, 00-975 Warszawa, Poland
}

Cybulska, D., Rubinkiewicz, J., 2020. The Apectodinium spp. acme as an evidence for the Paleocene-Eocene thermal maximum from the Polish Outer Carpathians. Geological Quarterly, 64 (2): 241-251, doi: 10.7306/gq.1521

Associate Editor: Stanisław Wołkowicz

Numerous Apectodinium taxa, with $A$. augustum, and the presence of Florentinia reichartii were found in the Bystre slice (Polish Outer Carpathians). Such abundance of Apectodinium is described for the first time in the Outer Carpathians. The occurrence of thermophilic Apectodinium taxa, with co-occurrence of Florentinia reichartii, are interpreted to be strongly related to the Paleocene-Eocene thermal maximum (PETM). The PETM is characterized by a notable global warming and changes in marine and terrestrial biota, such as a global dispersion of thermophilic dinoflagellates. We are also reporting a new, unrecorded section of the Hieroglyphic beds from the Jabłonka Stream.

Key words: Apectodinium, PETM, dinoflagellate cysts, Polish Outer Carpathians, Hieroglyphic Beds.

\section{INTRODUCTION}

The Paleocene-Eocene thermal maximum was a global hyperthermal event which took place $\sim 56$ million years ago (e.g., Westerhold et al., 2009; Zachos et al., 2010; Carmichael et al., 2017).

In the geological record, the PETM is characterized by a negative carbon isotope $\left(\delta^{13} \mathrm{C}\right)$ excursion (CIE) that indicates the release of ${ }^{13} \mathrm{C}$-depleted carbon into the ocean-atmosphere system (Kennett and Stott, 1991; Thomas et al., 2002; Pagani et al., 2006; Schouten et al., 2007).

This event was associated with the rise of deep-sea temperature by $\sim 5-6^{\circ} \mathrm{C}$ and the warming of sea surface temperatures (SST) by 5 to $8^{\circ} \mathrm{C}$ at low and high latitudes, respectively (e.g., Kennett and Stott, 1991; Thomas and Shackleton, 1996; Zachos et al., 2003; Tripati and Elderfield, 2005). The PETM is associated with significant changes in marine and terrestrial realms. Warming of the oceans caused the migration of thermophilic taxa (e.g., dinoflagellates Apectodinium and planktic foraminifera Acarinina) to the northern latitudes, the worldwide turnover of calcareous nannoplankton, and the extinction of benthic foraminifera due to anoxia (Kennett and Stott,

\footnotetext{
* Corresponding author, e-mail: d.cybulska@student.uw.edu.pl Received: July 30, 2019; accepted: September 19, 2019; first published online: March 12, 2020
}

1991; Thomas and Shackleton, 1996; Galeotti et al., 2004; Arreguín-Rodríguez et al., 2013).

One of the most significant changes associated with the PETM within marine plankton was the dispersion of the motile stage of tropical dinoflagellates of the Apectodinium genus (Bujak and Brinkhuis, 1998; Crouch et al., 2001, 2003a; Egger et al., 2003). Apectodinium evolved at low latitudes during the Danian-Selandian transition (Brinkhuis et al., 1994; Bujak and Brinkhuis, 1998). Apectodinium spp. dinoflagellates are interpreted as heterotrophic and thermophilic organisms linked to relative high SST and high nutrient availability (Powell et al., 1996; Bujak and Brinkhuis, 1998; Crouch et al., 2001, 2003b; Crouch and Brinkhuis, 2005; Shcherbinina et al., 2016), which occupied waters with temperatures exceeding $20^{\circ} \mathrm{C}$ (Frieling, 2016). High sea surface temperatures and nutrient availability related to the onset of PETM allowed Apectodinium to spread towards high latitudes (Bujak and Brinkhuis, 1998; Crouch et al., 2003b). Therefore, the high abundance of Apectodinium taxa in the fossil record is interpreted as an evidence for the PETM. Especially important is $A$. augustum, which is related to CIE (e.g., Bujak and Brinkhuis, 1998; Crouch et al., 2001, 2003b; Steurbaut et al., 2003; Sluijs et al., 2007).

The PETM-related acme of Apectodinium taxa is known from many locations around the globe, e.g.: in the North Sea (Bujak and Brinkhuis, 1998; Sluijs et al., 2008), Greenland (Nøhr-Hansen, 2003), Belgium (Steurbart et al., 2003), Austria (Heilmann-Clausen and Egger, 2000; Crouch et al., 2001), the Caucasus (Shcherbinina et al., 2016), Kazakhstan (lakovleva et al., 2001), Uzbekistan (Crouch et al., 2003b), North America (e.g., Sluijs et al., 2008; Sluijs and Brinkhuis, 2009), New Zea- 
land (Crouch et al., 2001, 2003a; Crouch and Brinkhuis, 2005; Sluijs et al., 2008), Antarctica (Bijl et al., 2013b) and Africa (Crouch et al., 2003b; Awad and Oboh-Ikuenobe, 2016; ObohIkuenobe et al., 2017).

In the Polish Outer Carpathians, Apectodinium taxa have been observed only sparsely (Gedl, 1995, 2005, 2013; Barsk and Bojanowski, 2010; Jurewicz and Segit, 2018) and are often interpreted as reworked (Gedl, 1995, 2005; Barski and Bojanowski, 2010). In nearby areas, in situ Apectodinium spp. were reported from the Rhenodanubian Flysch Zone (Mohamed and Wagreich, 2013).

This paper presents field-based studies and palynological analysis focused on the Apectodinium taxa, supported by stable carbon isotope $\left(\delta^{13} \mathrm{C}\right)$ analysis.

\section{GEOLOGICAL SETTING}

The study area is located in the eastern part of the Polish Outer Carpathians in the Bystre slice that is a tectonic element of the Silesian Nappe in the Bieszczady Mountains, south of Baligród (Ślączka, 1959; Cieszkowski et al., 1985; Mastella, 1995; Jankowski and Ślączka, 2014; Fig. 1). In this area, the Silesian Nappe is subdivided into two tectonic subunits: the Central Synclinorium (the Central Carpathian Depression) (Tołwiński, 1933; Świdziński, 1953; Oszczypko et al., 2008) and the Fore Dukla thrust-sheets (Świdziński, 1958; Oszczypko et al., 2008). The Bystre slice is a part of the Fore-Dukla thrustsheets (Cieszkowski et al., 1985; Mastella, 1995) and it is strongly tectonically deformed. The layers have undergone tectonic reduction. They are cut by thrusts, and secondary slices are present (Mastella, 1995). Therefore, the stratigraphic sections are generally discontinuous. The most detailed tectonic map of the Bystre slice along with the Fore-Dukla thrust-sheet was prepared by Mastella (1995).

Turbiditic sediments of the Bystre slice are dated to the Lower Cretaceous to Eocene (Ślaczka, 1959; Jankowski and Ślączka, 2014). During the Cretaceous to Early Eocene, the study area was a northern part of the Tethys Ocean, referred to as the Silesian Basin. The sedimentary system was controlled by tectonic processes and was dominated by turbidity currents (Golonka et al., 2000, 2006; Oszczypko, 2004).

\section{MATERIALS}

The Bystre slice is composed of seven lithostratigraphic units: the Cieszyn, Grodziszcze, Lgota, Godula, Istebna, and the Hieroglyphic Beds with the Cie kowice Sandstones at the bottom (Slączka, 1959; Jankowski and Ślączka, 2014). The section investigated in our study is described by Ślączka (1959) as the Lower Istebna Shales, assigned to the Paleocene.

In the present study we investigated a $21 \mathrm{~m}$ long outcrop section located south of the village of Bystre $\left(49^{\circ} 17^{\prime} 46.13^{\prime \prime} \mathrm{N}\right.$, $\left.22^{\circ} 16^{\prime} 11.56 " E\right)$ along the Jabłonka Stream. Field investigation reveals an unrecorded section of the Eocene Hieroglyphic Beds. It is represented here by the typical green marly shale with few intercalations of variegated (red) shales and a thin to medium bedded, fine-grained sandstones with silica cementation (Fig. 2A, B). Sandstones are green and grey-green in colour. At the base of the sandstones, organic hieroglyphs are present, which is typical for the Hieroglyphic Beds (Fig. 2C). Additionally, greenish sandstones and conglomerates occur at the bottom of Hieroglyphic Beds, which are probably a part of the Cie kowice Sandstones (Beds). At the top of the section, a breccia zone is present (Fig. 2D). Above the section (upstream), there is a typical profile of the Istebna Beds. The section indicates the existence of an unrecorded thrust of the Istebna Beds resting on the Eocene Hieroglyphic Beds, and thus the tectonic repetition (Fig. 3).

A similar but thicker $(\sim 100 \mathrm{~m})$ section of the Hieroglyphic Beds with Cię kowice Sandstones at the bottom, is revealed in the same stream a few hundred metres upstream.

Samples for microplaeontological analysis were taken from shale intervals. We collected 20 sediment samples, labelled from 1 to 18.87, and the number for each sample corresponds to the position in the section (Fig. 4). In this study, we are focused on organic-walled dinoflagellate cysts, mostly on the Apectodinium group.

\section{METHODS}

Samples have been subjected to the standard palynological preparation technique proposed by Poulsen et al. (1990). Twenty grams of sediment were treated with $38 \%$ hydrochloric $(\mathrm{HCl})$ and $40 \%$ hydrofluoric (HF) acids to dissolve carbonates and silica, respectively. The residuum was sieved through a $15 \mathrm{~m}$ nylon mesh. A heavy liquid separation $\left(\mathrm{ZnCl}_{2}\right.$ density $=2 \mathrm{~g} / \mathrm{cm}^{3}$ ) was applied. Palynological slides were prepared using glycerin jelly as a mounting medium. Due to the insufficient material, two palynological slides from each sample were examined. Wherever possible, 300 dinoflagellate cysts taxa were counted. Samples with a high amount of Apectodinium taxa were also examined with fluorescent microscopy to estimate the ratio of reworking causing abnormal concentration. The palynological analyses were conducted at the Faculty of Geology, University of Warsaw, where all slides are stored.

To examine the content of $\delta^{13} \mathrm{C}$ in the studied material, which could be correlated with PETM, samples for bulk organic carbon isotopes have been analysed.

Bulk organic carbon isotopes $\left(\delta^{13} \mathrm{C}_{\text {org }}\right)$ were measured on 11 samples which were taken from intervals of increased Apectodinium taxa abundance. For this purpose, we collected $\sim 0.3 \mathrm{~g}$ of residue which was demineralized, neutralized, and finally dried. Carbon isotopes are reported relative to Vienna Peedee Belemnite (VPDB). The analytical error is $\pm 0.4 \%$ o. The analysis was made at the Institute of Geological Sciences, Polish Academy of Sciences, using an isotope ratio mass spectrometer (IRMS) Thermo Delta V Advantage coupled in a continuous flow system with a Thermo Flash EA 1112HT elemental analyser.

\section{RESULTS}

\section{DINOFLAGELLATE CYSTS}

Palynological slides from all depths yield both dinoflagellate cysts and rich terrestrial phytoclasts. Only four samples are barren of dinoflagellate cyst (samples $1 ; 12 ; 15,6$ and 18,87). In six samples $(4,5 ; 7,5 ; 9 ; 12,75 ; 14 ; 16)$, dinocysts were rare, below 60 specimens per sample, and we did not include those samples in our final consideration. Only 10 samples yield abundant 


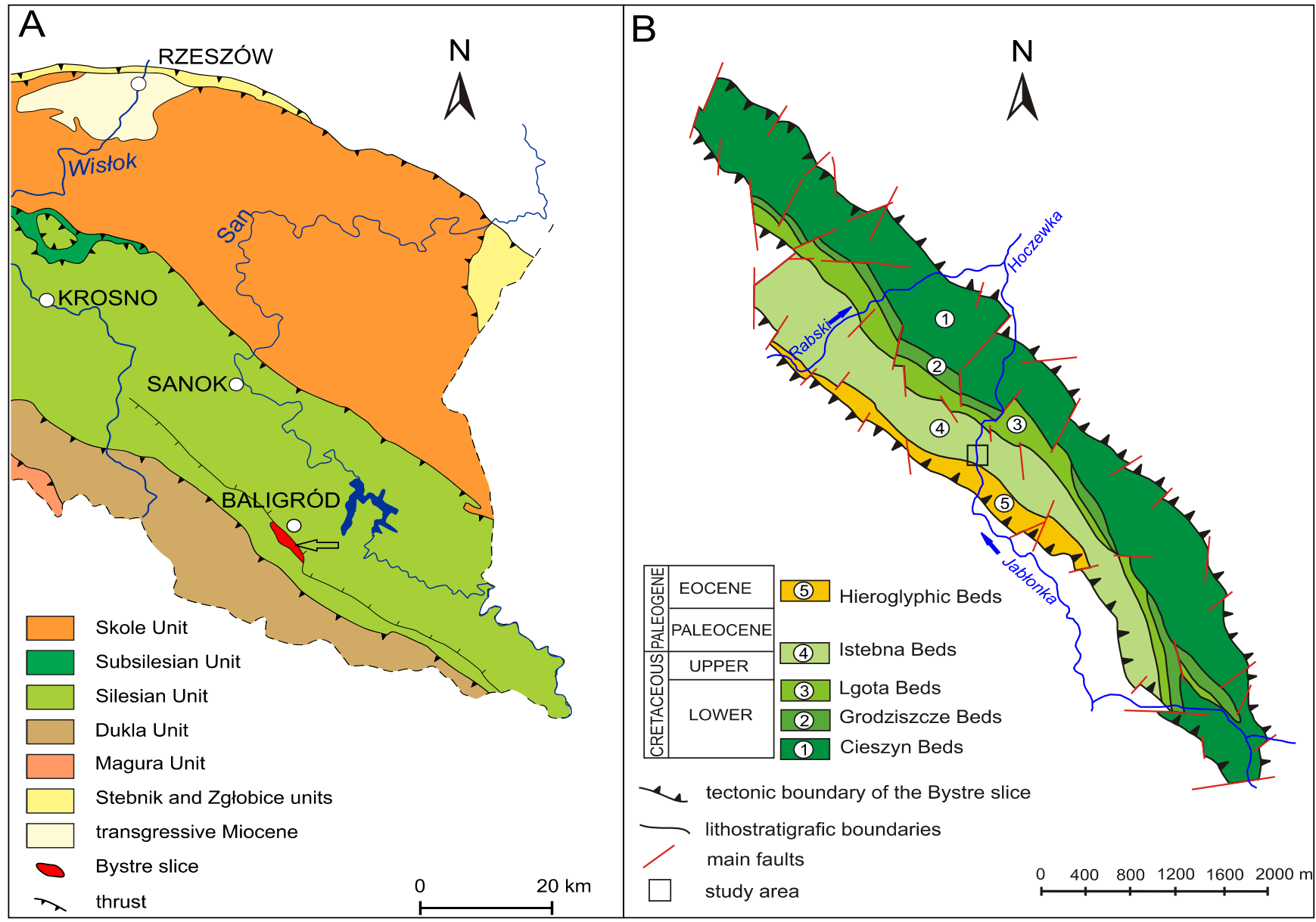

Fig. 1A - location of the study area on the map of the Polish Outer Carpathians (modified from ytko et al., 1989); B - lithostratigraphical map of the Bystre slice (modified from Mastella, 1995)

and highly diversified dinoflagellate cyst assemblages (Appen$\left.\operatorname{dix} 1^{*}\right)$.

The richness of dinoflagellate cyst assemblages differs between the samples. In total, 69 genera and 65 species have been recognized (Appendices 1 and 2), including reworked taxa. The material is dominated by Apectodinium, Glaphyrocysta, Adnatosphaeridium, Cleistosphaeridium, Spiniferites and Areoligera (Figs. 5-7).

The dinoflagellate assemblages abound in the genus Apectodinium that predominates in eight samples, accounting for $\sim 25-\sim 37 \%$ of the total dinoflagellate cyst assemblage (Figs. 5 and 6). In samples 5,4 and 6,5 Apectodinium are common but do not exceed $15 \%$. In samples 3,5 and 7, Apectodinium specimens are scarce and do not exceed $6 \%$.

Apectodinium appears in two abundance intervals of 5.4-7.0 $\mathrm{m}$ and 9.5-11.1 $\mathrm{m}$. In the former, Apectodinium attains almost $28 \%$ of total dinocysts, whereas in the latter, it is even more abundant (25-37\% of the total dinocyst assemblage) (Fig. 5).

All samples containing Apectodinium sp. are dominated by A. homomorphum $-29 \%$ of the dinoflagellate cyst assemblage. $A$. augustum dinoflagellate cysts are present, but they are rela- tively rare, up to $3.5 \%$ of the dinoflagellate cyst assemblage (Fig. 6A-D). Apectodinium augustum was recently transferred to a new genus, Axiodinium (Williams et al., 2015), however, we follow the suggestion of Bijl et al. (2016) and retain the former name of the taxon.

Between 7.0 and $9.5 \mathrm{~m}$, we observe the disappearance of Apectodinium with numerous inceptions of Adnatosphaeridium (17 and 41\%) and Glaphyrocysta ( 33, 32 and 31\%)(Fig. 7B, G, $\mathrm{H}, \mathrm{M})$. Areoligera sp. is characterized by a similar distribution pattern. Spiniferites sp. and Cleistosphaeridium sp. are abundant and their distribution is similar to the Apectodinium (Fig. 5).

We find a thin interval of common Florentinia reichartii ( 9\%) (Figs. 5 and 6C, D) co-occurring with the first peak of Apectodinium spp. in sample 5,9. A single specimen of $F$. reichartii is also noted in samples 7 and 9,5.

Samples examined in fluorescent microscopy show differences in colour only in the case of recycled Cretaceous dinoflagellate cysts (Fig. 7R, S). All specimens of Apectodinium revealed similar autofluorescence. This allows us to treat all Apectodinium taxa and other Paleogene dinoflagellate taxa in situ (Figs. 6 and 7B-H, J-P).

\footnotetext{
* Supplementary data associated with this article can be found, in the online version, at doi: 10.7306/gq.1521
} 

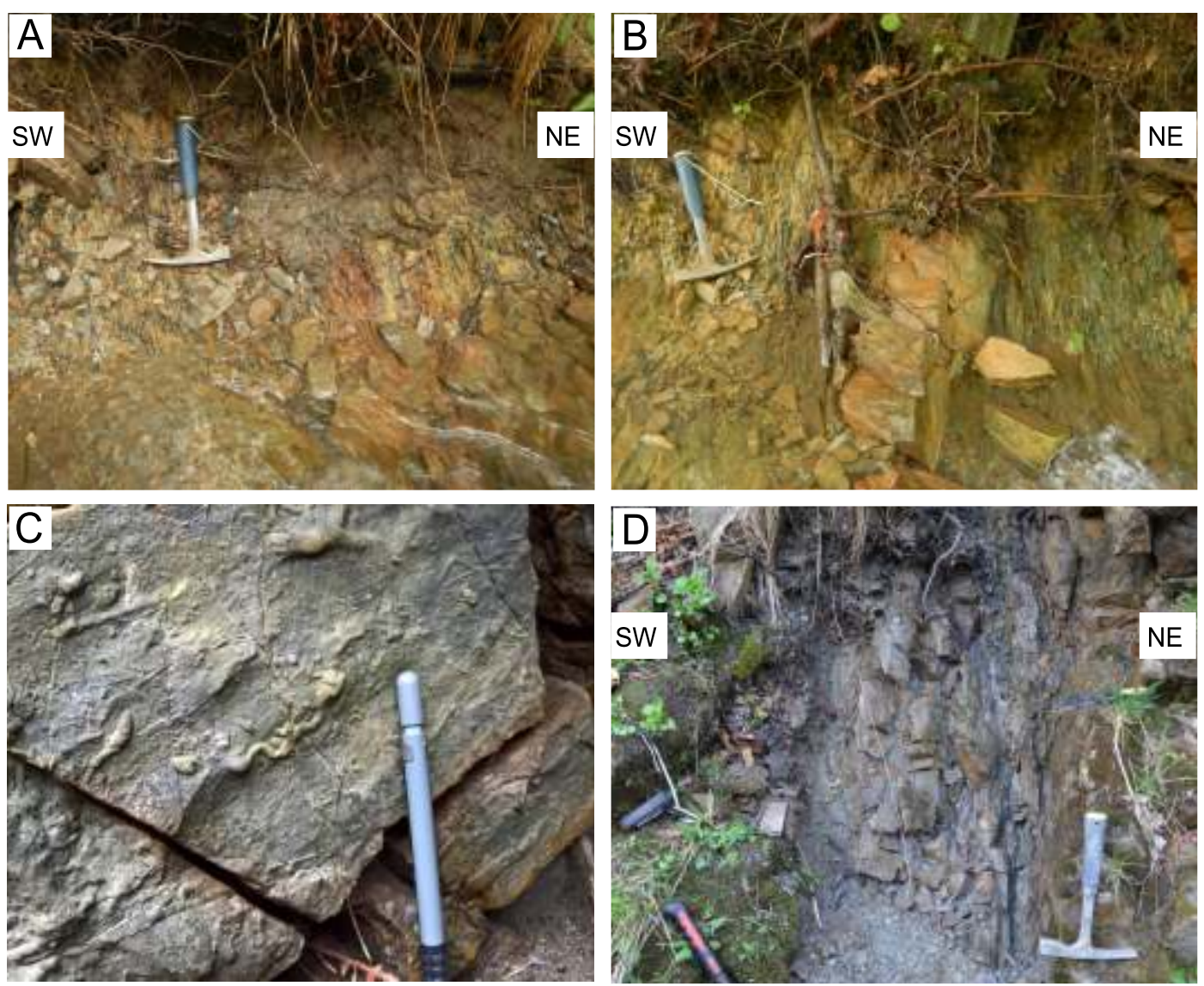

Fig. 2. Photographs from the section studied

A, B - shales and sandstones of the Hieroglyphic beds; C - organic hieroglyphs at the base of sandstone; D - tectonic breccia at the top of the section (phot. Maciej Łoziński)
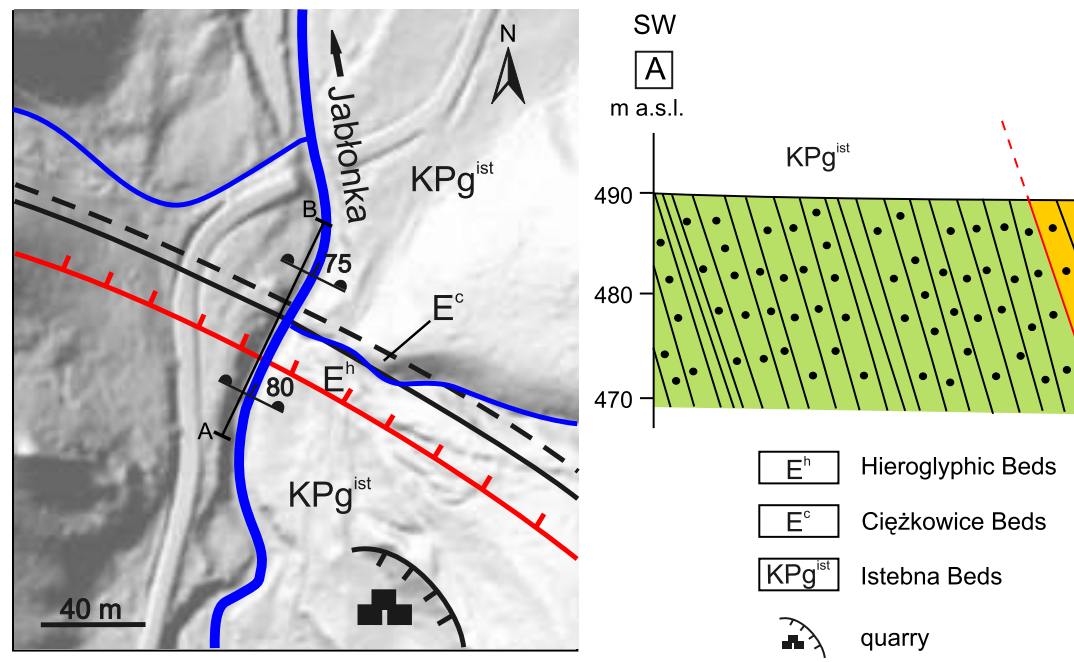

Fig. 3. Simplified map and the cross-section of the study area

Digital Terrain Model source: www.geoportal.gov.pl 


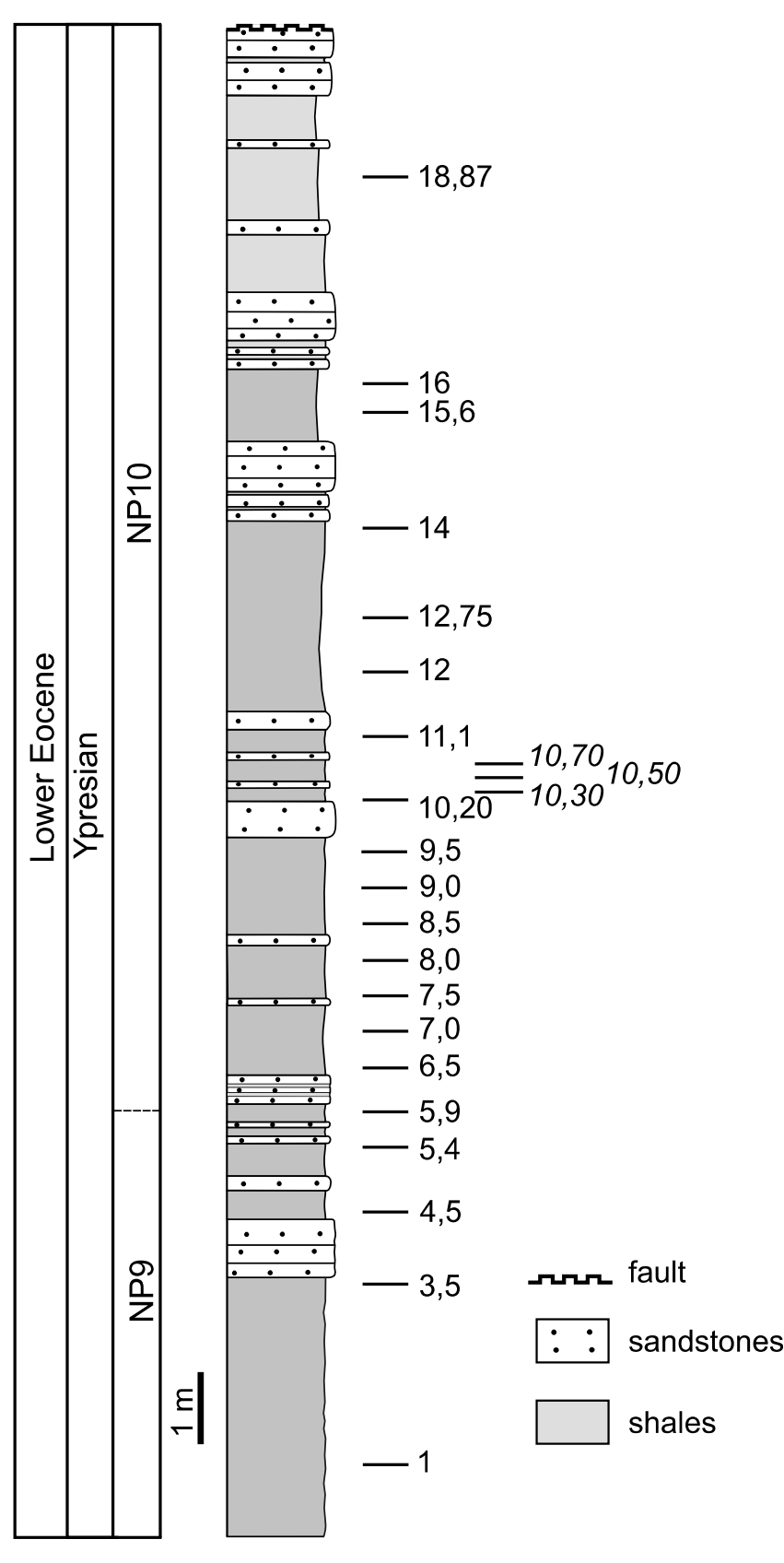

Fig. 4. Simplified lithological profile of the outcrop section along the Jabłonka Stream

Numbers to the right correspond to the sample numbers; numbers in italics correspond to additional isotopic samples

\section{STABLE CARBON ISOTOPES}

We focused on intervals where the occurrence of Apectodinium sp. is palynologically proved, from sample 3,5 to 7,0 and from 9,5 to 11,1 . In the studied interval, the carbon isotope $\delta^{13} \mathrm{C}_{\text {org }}$ values range from -23 to $-27.7 \%$ (Fig. 5). We observe isotope values with a signature of $-27.2 \%$ at sample 3,5 and an increase in values in the upper part of the interval. In sample 6,5 , the $\delta^{13} \mathrm{C}_{\text {org }}$ reaches a value of -23.7 and $-24.4 \%$ in sample 7,0. We noticed the reappearance of Apectodinium sp. in sample 9,5 where the $\delta^{13} \mathrm{C}_{\text {org }}$ is $-23.3 \%$. From this level isotope, the values evince a tendency to decline, with a distinctly negative trend towards sample 10.3 with a minimal signature of $-27.7 \%$ o (Fig. 5). The next three samples $(10,5 ; 10,7 ; 11,1)$ indicate a gradual increase. The topmost sample 11,1 reach the $\delta^{13} \mathrm{C}_{\text {org }}$ value of $-23.0 \%$. In the samples below 3,5 and above 11,1 the bulk organic isotope analysis is non-substantive due to organic content dominated by terrestrial tissues and significant absence of marine microplankton.

\section{AGE}

Biostratigraphic analysis based on dinoflagellate cysts reveals Early Eocene-lowest Ypresian age, nannoplankton zones NP9 and NP10 of Martini (1971).

The presence of Apectodinium spp. indicates Late Paleocene to Early Eocene age (Costa and Downie, 1976; Powell, 1992). Williams and Bujak (1985) documented that $A$. homomorphum ranges from the Upper Paleocene to the Middle Eocene. The presence of Apectodinium homomorphum and $A$. quinquelatum (Fig. $6 \mathrm{H}$ ) indicates the $A$. hyperacanthum Zone of Costa and Downie (1976), suggesting a Late Paleocene to Early Eocene age. The presence of $A$. augustum, which is recorded only from the CIE (Bujak and Brinkhuis, 1998; Steurbaut et al., 2003; Sluijs et al., 2007), suggests the Late Paleocene to Early Eocene, Zone NP9 of Martini (1971; Powell, 1992; Williams et al., 2004). Phelodinium magnificum (Fig. 70) indicates the Early Eocene, Zone NP10 of Martini (1971; Powell, 1996). Florentinia reichartii is a very important species. Its stratigraphic occurrence is very narrow, spanning the latest Paleocene and earliest Eocene (Sluijs and Brinkhuis, 2009). The ranges of Homotryblium tenuispinosum and Adnatosphaeridium vittatum are problematic. According to Powell (1992) the first appearance of $H$. tenuispinosum is in the mid-Ypresian NP11 of Martini (1971), but according to Williams et al. (2004) the first occurrence of this species in the northern Hemisphere (mid-latitudes) is in the Thanetian, before Apectodinium augustum. Similarly Adnatosphaeridium vittatum (as Adnatosphaeridium multispinosum) on global charts is limited to the Eocene, and according to Powell (1992) and Stover et al. (1996) it appeared for the first time in the mid-Ypresian. However, Eaton (1976) gives its first occurrence in the latest Paleocene. Moreover, Adnatosphaeridium multispinosum was recognized in the Late Paleocene of Nigeria (Jan du Chęne and Adediran, 1984) and Tunisia (Kocsis et al., 2014). Sánchez-Pellicer et al. (2017) report the first appearance of this species in the Selandian in the Gulf of Guinea.

\section{DISCUSSION}

\section{DINOFLAGELLATE CYSTS}

Apectodinium taxa are present in a majority of samples containing dinoflagellate cysts; in a few of them they are dominant, ranging from $\sim 25$ to $\sim 37 \%$ of the dinoflagellate cyst assemblage. This high number of Apectodinium taxa from the Polish Outer Carpathians has been noted for the first time.

In the Bystre slice the maximum occurrence reaches $~ 37 \%$, whereas, for example, it exceeds $60 \%$ at the Anthering section in Austria (Heilmann-Clausen and Egger, 2000; Crouch et al., 


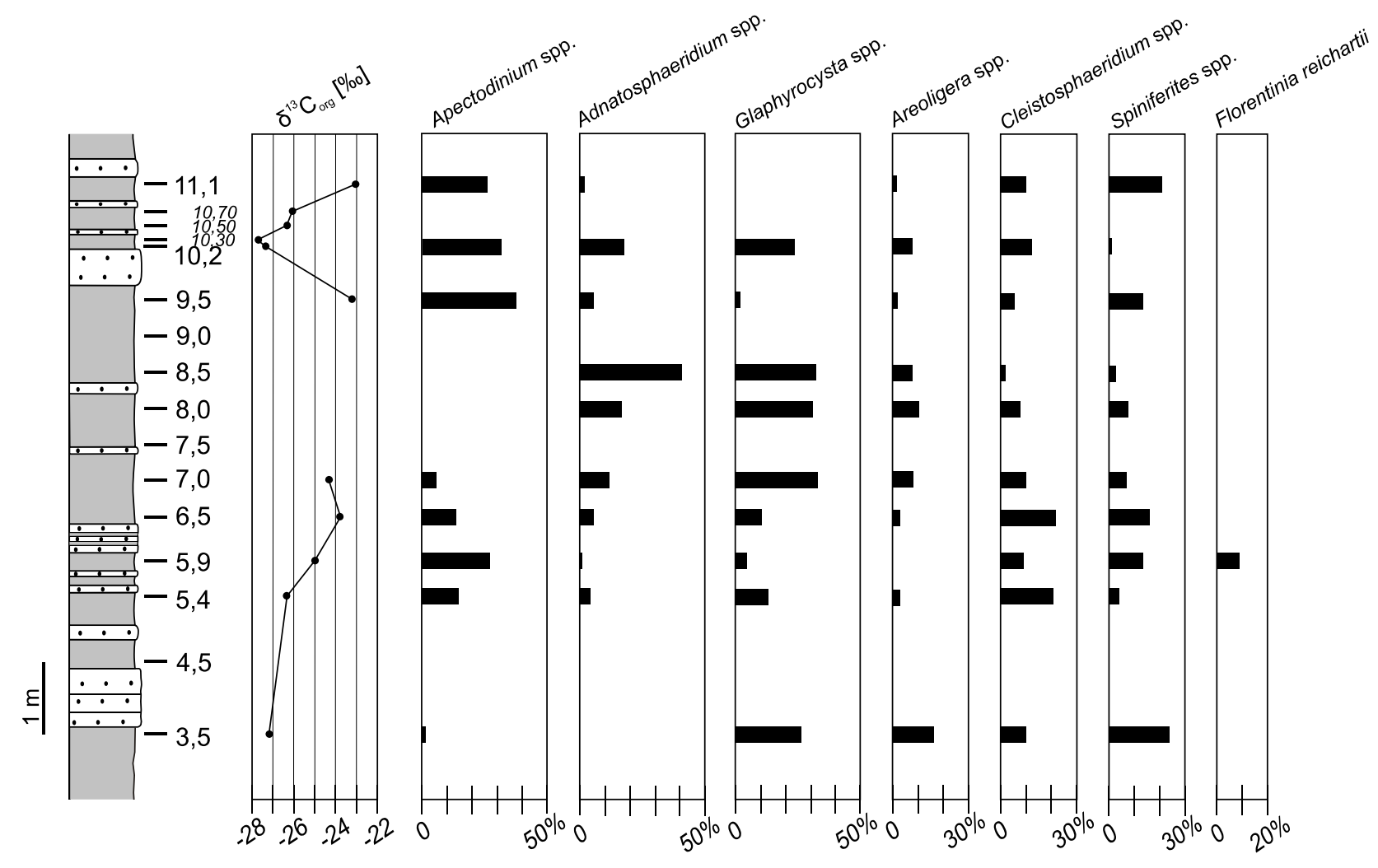

Fig. 5. Part of the study section showing the $\delta^{13} \mathrm{C}_{\text {org }}$ isotope records and the percentage distribution of main groups of dinoflagellate cysts

2001), $70 \%$ at the Kheu section, Caucasus (Shcherbinina et al., 2016), $>90 \%$ at the Tienen Formation, Belgium (Steurbaut et al., 2003), and $\sim 60 \%$ at the Tawanui section, New Zealand (Crouch et al., 2001, 2003a). However, at the Aktumsuk section, Uzbekistan, Crouch et al. (2003b) reported the occurrence of Apectodinium up to $\sim 35 \%$ of the assemblage. It should be mentioned that both the Bystre and Aktumsuk sections were within the northern Tethys realm in the Late Paleocene/Lower Eocene (Bolle et al., 2000; Oszczypko, 2004; Golonka, 2006). In the studied material, Apectodinium augustum is actually uncommon, reaching $3.5 \%$ of the assemblage. Previous studies show that $A$. augustum is sometimes not even recorded in the PETM sections (Crouch et al., 2003b; Frieling et al., 2018b).

One of the interesting features of our study is the two peaks of Apectodinium abundance with values $\sim 28$ and $\sim 37 \%$. Similar features of abundance peaks are recorded in other locations with the PETM, e.g. at the Tienen Formation (Steurbaut et al., 2003) and the Elles section (three peaks) (Crouch et al., 2003b). They are referred to other Late Paleocene and Early Eocene Apectodinium occurrences in the Northern Hemisphere (Powell et al., 1996; Bujak and Brinkhuis, 1998; Crouch et al., 2003b; Steurbaut et al., 2003).

Dinoflagellate cysts from Bystre indicate an Early Eocene age. It could be coeval with other Early Eocene sections, e.g. Jebel Boudabous (Bujak and Brinkhuis, 1998) and Aktumsuk (Crouch et al., 2003b).

In the part of the section where Apectodinium disappears or is scarce, a significant increase of the Areoligera complex (Areoligera sp., Adnatosphaeridium sp., Glaphyrocysta sp.) is noted. Motile Apectodinium dinoflagellates probably fed on organic detritus and other plankton (Bujak and Brinkhuis, 1998). They are typical of neritic and coastal (lagoonal, estuarine or brackish) settings with low salinities (Stover et al., 1996). In contrast, the Areoligera complex is interpreted as autotrophic dinoflagellates, linked mostly with inner neritic settings (Brinkhuis, 1994; Powell et al., 1996) and also found in high-energy marginal marine environments (Stover et al., 1996; Shcherbinina et al., 2016). Within secondary dinoflagellate assemblages, Spiniferites and Cleistosphaeridium spp. are common. Spiniferites sp. appears in both ocean and neritic settings (Brinkhuis, 1994); Cleistosphaeridium sp. is linked to normal marine, shallow water (Köthe, 1990).

The disappearance of heterotrophic Apectodinium and the significant increase of the autotrophic Areoligera complex probably indicate changes in nutrient delivery. There must have been a factor controlling the supply of nutrients, for instance, sea level changes. The Silesian Basin, like other Carpathian basins, was controlled by tectonic processes (Oszczypko, 2004; Golonka, 2006) and this could have had a significant impact on sea level changes and thus the nutrient supply. Consequently, Apectodinium is associated with a coastal environment, so an increase in sea level could have an impact on their distribution.

Along with the acme of Apectodinium spp. the occurrence of Florentinia reichartii has been noted herein for the first time in the Outer Carpathians. This species is described from the New Jersey Shelf (Sluijs and Brinkhuis, 2009), East Tasman Plateau (Sluijs et al., 2011), South Pacific Ocean (Bijl et al., 2013a) and the Otway Basin, Australia - where it was treated as a marker species for the PETM (Frieling et al., 2018a). F. reichartii also was thermophilic, but the temperature range for this species was $>30^{\circ} \mathrm{C}$ (Frieling, 2016). The presence of $F$. reichartii may indicate warming of sea surface waters more than is assumed with the occurrence of Apectodinium. 

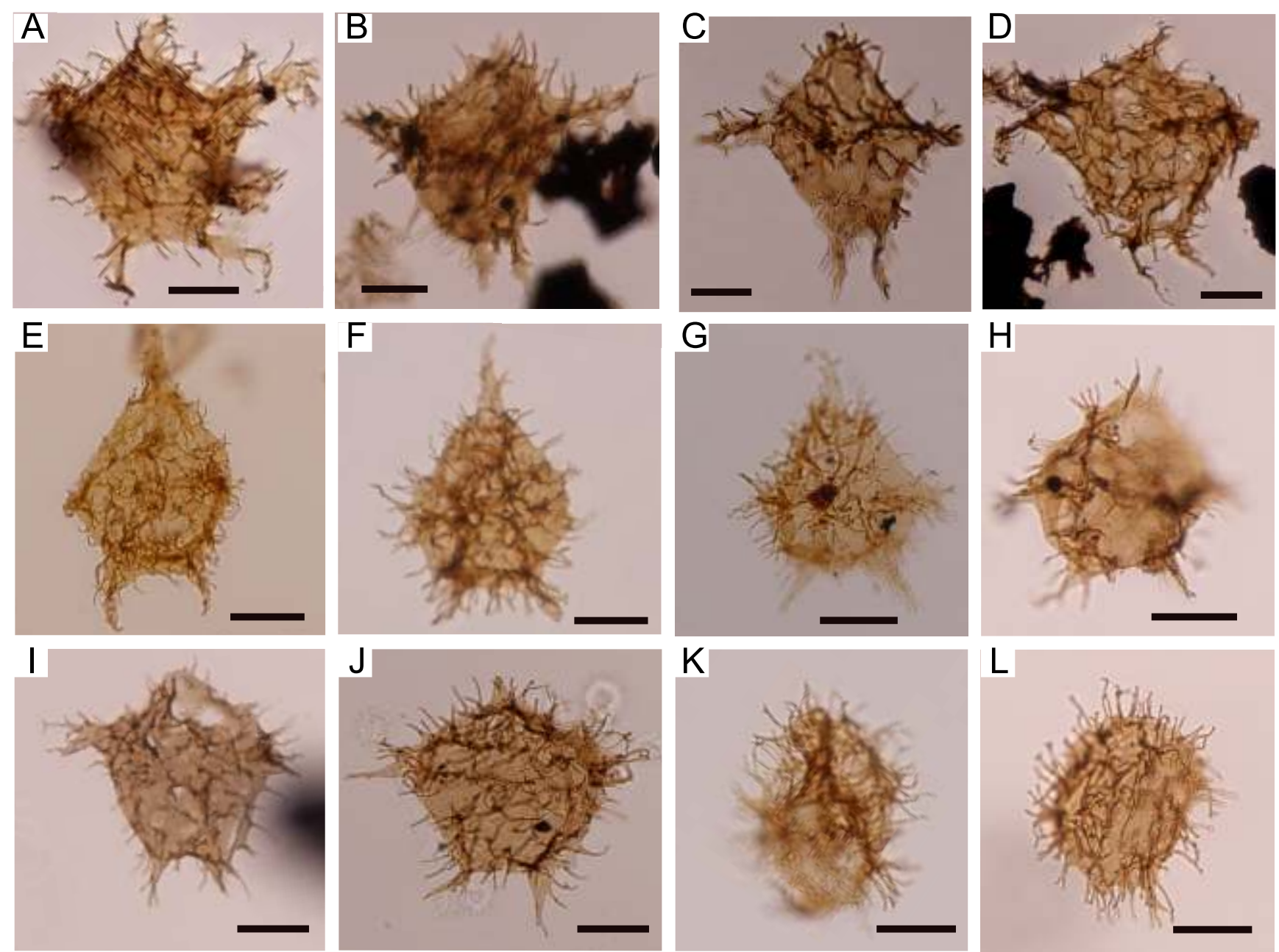

Fig. 6. Light microscope images for the Apectodinium group

A-D - Apectodinium augustum (sample 10,20); E - Apectodinium longispinosum (sample 5,9); F, G - Apectodinium parvum (samples 10,20; 5,9); H - Apectodinium quinquelatum (sample 10,20); I, J - Apectodinium hyperacanthum (samples 7; 3,5); K, L - Apectodinium homomorphum (samples 10,20; 11.1); scale bar $=25 \mathrm{~m}$

\section{CARBON ISOTOPE}

Stable carbon isotope analysis is a standard method for determining the source of organic matter in modern and ancient environments, especially to trace proportions of phytoplankton and terrestrial organic matter. The source of suspended or buried organic matter is determined from bulk isotopic data; therefore, evaluation of the proportion of the pure marine and pure terrestrial elements is an important question (Calder and Parker, 1968; Newman et al., 1973). There are also other factors influencing the organic matter distribution pattern, including: e.g. regional and local terrestrial and marine floras variations, seasonal and spatial variability, degradative processing, and various external and internal transport pathways in/to sedimentary basins (Stiller, 1977). Recycling of particulate, especially terrestrial organic matter, which is resistant to mechanical and chemical damage, is a common geological process within flysch-type deposits. Moreover, omnipresent in clastic environments, submarine erosion is also capable of reworking ancient marine particles including dinoflagellate cysts, acritarcha, and foraminifera test linings potentially influencing the isotopic signal. Therefore, all kinds of anomalies should not be underestimated.

In our material, we have noticed several evidences of reworking of Cretaceous and Jurassic dinoflagellate (Fig. 7A, I, R, S); therefore, recycling of other older organic particles must be considered. According to Tyson (1993) the recycled terrestrial material of Mesozoic age tends to shift isotopic signatures to be heavier.

Our $\delta^{13} \mathrm{C}_{\text {org }}$ values served only as reference points to previous PETM values occurring around this global phenomenon. The analysis shows $\delta^{13} \mathrm{C}_{\text {org }}$ values between -23 and $-27.7 \%$ 。 and seems to be similar to other $\delta^{13} \mathrm{C}_{\text {org }}$ analysis from the PETM in Europe (Steurbaut et al., 2003; Thiry et al., 2006; Collinson et al., 2009). However, due to the high ratio of recycling we are aware that the method can yield only poor or ambiguous results in our case. This is the main reason we believe rather in a palaeontological signal reflected by increased number of Apectodinium genera. To ensure that our palaeontological results are reliable we excluded the reworking process of Apectodinium specimens by means of autofluorescence excited by ultraviolet light. After microscopic examination, all specimens of Apectodinium occurring in the samples around the PETM re- 

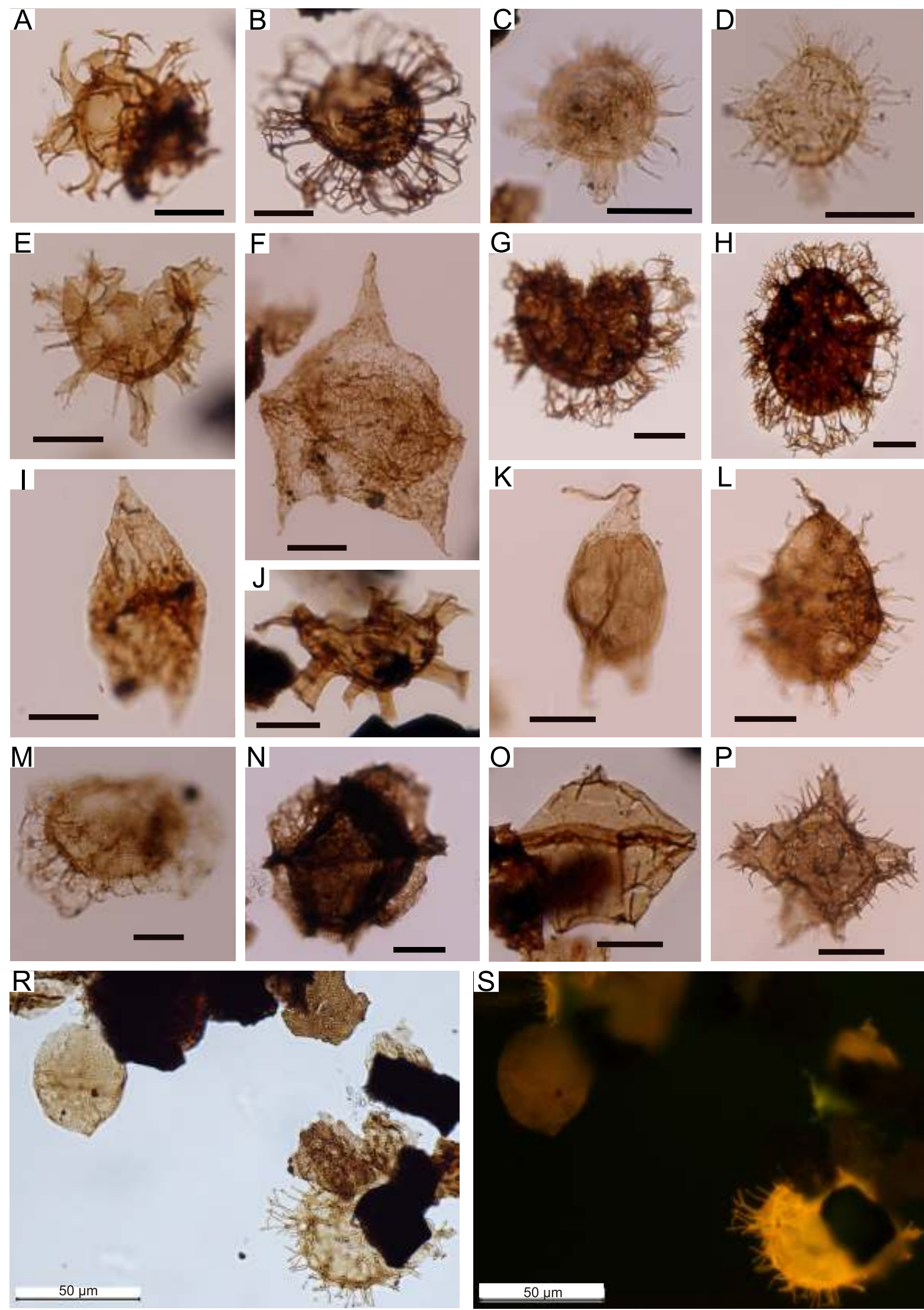

Fig. 7. Light microscope images for the selected dinoflagellate cysts

A - Areoligera neptuni (sample 6,5); B - Adnatosphaeridium vittatum (sample 8,5); C, D - Florentinia reichatrii (sample 5,9); E Hystrichokolpoma rigaudiae (sample 6,5); F-Deflandrea oebisfeldensis (sample 5,9); G, H - Glaphyrocysta divaricata (samples 8.5; 7); I- Isabelidinium sp. (sample 5,9); J - Homotryblium abbreviatum (sample 11,1); K - Cerodinium diebelii (sample 5,9); L Fibrocysta bipolaris (sample 5,4); M - Glaphyrocysta microfenestrata (sample 5,9); N - Muratodinium sp. (sample 8); $\mathbf{O}-$ Phelodinium magnificum (sample 5,9); P - Wilsonidium sp. (sample 7); R, S - Apectodinium sp. and reworked Subtilisphaera sp. in transmitted light and UV (sample 5,9); A-P: scale bar $=25 \mathrm{~m} ; \mathrm{R}$ and S: scale bar $=50 \mathrm{~m}$ 
cord, revealed a similar autofluorescence level. On the one hand, it proves in situ character of this record, and on the other, reduces probability of artificial concentration of these taxa.

\section{CONCLUSIONS}

The study reveals a high number of Apectodinium dinoflagellate cysts in the material from the Outer Carpathians. Apectodinium augustum is particularly important. Being a marker taxon, it indicates the PETM record in this area. The presence of Florentinia reichartii has also been recorded. Likewise, the Apectodinium species is thermophilic and related to the PETM. Changes in the content of Apectodinium and their substitution by the Areoligera complex may indicate sea level changes and/or delivery of nutrients.
Our study reveals also an unrecorded section of the Eocene Hieroglyphic beds and the existence of the Istebna Beds thrust over the Hieroglyphic Beds, which indicates tectonic repetition.

Acknowledgements. We are grateful to Dr M. Barski for the great help and discussion. Dr M. Bojanowski and Dr W. Kozłowski are thanked for valuable remarks in interpretation of isotopic analysis. We would like to thank Dr M. Łoziński for help in field work, and E. Demianiuk and T. Plasota for critical reading of a previous version of this manuscript. $P$. Steele is thanked for English linguistic improvements. We would like to thank Prof. A. Konon and the second, anonymous reviewer for comments which significantly improved this paper. This study was supported by an internal grant of the Faculty of Geology, University of Warsaw.

\section{REFERENCES}

Arreguín-Rodríguez, G.J., Alegret, L., Ortiz, S., 2013. Glomospira acme during the Paleocene-Eocene thermal maximum: response to $\mathrm{CaCO}_{3}$ dissolution or to ecological forces? Journal of Foraminiferal Research, 43: 40-54.

Awad, W.K., Oboh-lkuenobe, F.E., 2016. Early Paleogene dinoflagellate cysts from ODP Hole 959D, Côte d'Ivoire-Ghana transform margin, west Africa: new species, biostratigraphy and paleoenvironmental implications. Journal of African Earth Sciences, 123: 123-144.

Barski, M., Bojanowski, M., 2010. Organic-walled dinoflagellate cysts as a tool to recognize carbonate concretions: an example from Oligocene flysch deposits of the Western Carpathians. Geologica Carpathica, 61: 121-128.

Bijl, P.K., Sluijs, A., Brinkhuis, H., 2013a. A magneto- and chemostratigraphically calibrated dinoflagellate cyst zonation of the early Palaeogene South Pacific Ocean. Earth-Science Reviews, 124: 1-31

Bijl, P.K., Bendle, A.P.J., Bohaty, S.M., Pross, J., Schouten, S., Tauxe, L., Stickley, C.E., McKay, R.M., Röhl, U., Olney, M., Sluijs, A., Escutia, C., Brinkhuis, H., Expedition 318 scientists, 2013b. Eocene cooling linked to early flow across the Tasmanian Gateway. Proceedings of the National Academy of Sciences of the United States of America, 110: 9645-9650.

Bijl, P.K., Brinkhuis, H., Egger, L.M., Eldrett, J.S, Frieling, J., Grothe, A., Houbene, A.J.P., Pross, J., Śliwińska, K.K., Sluijs, A., 2016. Comment on "Wetzeliella and its allies - the 'hole' story: a taxonomic revision of the Paleogene dinoflagellate subfamily Wetzelielloideae" by Williams et al. (2015). Palynology, 41: 423-429.

Bolle, M.-P., Pardo, A., Hinrichs, K.-U., Adatte, T., Von Salis, K., Burns, S., Keller, G., Muzylöv, N., 2000. The Paleocene-Eocene transition in the marginal northeastern Tethys (Kazakhstan and Uzbekistan). International Journal of Earth Sciences, 89: 390-414.

Brinkhuis, H., 1994. Late Eocene to Early Oligocene dinoflagellate cysts from the Priabonian type-area (Northeast Italy): biostratigraphy and paleoenvironmental interpretation. Palaeogeography. Palaeoclimatology, Palaeoecology, 107: 121-163.

Brinkhuis, H., Romein, A.J.T., Smit, J., Zachariasse, J-W., 1994. Danian-Selandian dinoflagellate cysts from lower latitudes with special reference to the El Kef section, NW Tunisia. GFF, 116 $46-48$.

Bujak, J.P., Brinkhuis, H., 1998. Global warming and dinocyst changes across the Paleocene-Eocene epoch boundary. In: Late Paleocene-Early Eocene (eds. M.-P. Aubry and W.A. Berggren): 277-295. Columbia University Press, New York.
Burtan, J., 1936. Stratigraphie der Schlesisien Beskiden. Stratigraphie der schlesischen Beskiden. Bulletin International de L'Academie Polonaise des Sciences et des Lettres de Cracovie: $1-41$.

Calder, J.A., Parker, P.L., 1968. Stable carbon isotope ratios as indices of petrochemical pollution of aquatic systems. Environmental Science and Technology, 2: 535-593.

Carmichael, M.,J., Inglis, G.N., Badger, M.P.S., Naafs, B.D.A., Behrooz, L., Remmelzwaal, S., Monteiro, F.M., Rohrssen, M., Farnsworth, A., Buss, H.L., Dickson A.J., Valdes, P.J., Lunt, D.J., Pancost, R.D., 2017. Hydrological and associated biogeochemical consequences of rapid global warming during the Paleocene-Eocene Thermal Maximum. Global and Planetary Change, 157: 114-138.

Cieszkowski, M., Ślączka, A., Wdowiarz, A., 1985. New data on structure of the Flysch Carpathians. Przegląd Geologiczny, 33: 313-332.

Collinson, M.E., Steart, D.C., Harrington, G.J., Hooker, J.J., Scott, A.C., Allen, L.O., Glasspool, I.J., Gibbons, S.J., 2009. Palynological evidence of vegetation dynamics in response to palaeoenvironmental change across the onset of the Paleocene -Eocene Thermal Maximum at Cobham, Southern England. Grana, 48: 38-66.

Costa, L.I., Downie, C., 1976. The distribution of the dinoflagellate Wetzeliella in the Palaeogene of north-western Europe. Palaeontology, 19: 591-614.

Crouch, E.M., Brinkhuis, H., 2005. Environmental change across the Paleocene-Eocene transition from eastern New Zealand: a marine palynological approach. Marine Micropaleontology, 56: 138-160.

Crouch, E.M., Heilmann-Clausen, C., Brinkhuis, H., Morgans, H.E.G., Rogers, K.M., Egger, H., Schmitz, B., 2001. Global dinoflagellate event associated with the late Paleocene thermal maximum. Geology, 29: 315-318.

Crouch, E.M., Dickens, G.R., Brinkhuis, H., Aubry, M.-P., Hollis, C.J., Rogers, K.M., Visscher, H., 2003a. The Apectodinium acme and terrestrial discharge during the Paleocene-Eocene thermal maximum: new palynological, geochemical and calcareous nannoplankton observations at Tawanui, New Zealand. Palaeogeography, Palaeoclimatology, Palaeoecology, 194: 387-403.

Crouch, E.M., Brinkhuis, H., Visscher, H., Adatte, T., Bolle, M.-P., 2003b. Late Paleocene-early Eocene dinoflagellate cyst records from the Tethys: Further observations on the global distribution of Apectodinium. GSA Special Paper, 369: 113-131. 
Eaton, G.L., 1976. Dinoflagellate cysts from the Bracklesham Beds (Eocene) of the Isle of Wight, southern England. Bulletin of the British Museum (Natural History). Geology, 26: 227-332.

Egger, H., Fenner, J., Heilmann-Clausen, C., Rögl, F., Sachsenhofer, R.F., Schmitz, B., 2003. Paleoproductivity of the northwestern Tethyan margin (Anthering Section, Austria) across the Paleocene-Eocene transition. GSA Special Paper, 369: 133-146.

Frieling, J., 2016. Climate, Carbon Cycling and Marine Ecology during the Paleocene Eocene Thermal Maximum. Ph.D. thesis, Utrecht University, Utrecht, Netherlands.

Frieling, J., Huurdeman, E.P., Rem, C.C.M., Donders, T.H., Pross, J., Bohaty, S.M., Holdgate, G.R., Gallagher, S.J., McGowran, B., Bijl, P.K., 2018a. Identification of the Paleocene-Eocene boundary in coastal strata in the Otway Basin Victoria, Australia. Journal of Micropalaeontology, 37: 317-339.

Frieling, J., Reichart, G-J., Middelburg, J.J., Röhl, U., Westerhold, T., Bohaty, S.M., Sluijs A., 2018b. Tropical Atlantic climate and ecosystem regime shifts during the Paleocene-Eocene Thermal Maximum. Climate of the Past, 14: 39-55.

Galeotti, S., Kaminski, M.A., Coccioni, R., Speijer, R.P., 2004 High-resolution deep-water Agglutinated Foraminiferal record across the Paleocene/Eocene transition in the Contessa Road Section (central Italy). Grzybowski Foundation Special Publication, 8: 83-103.

Gedl, P., 1995. Middle Eocene dinoflagellate cysts from the Rogoźnik section, Flych Carpathians, Poland. Acta Palaeobotanica, 35: 195-231.

Gedl, P., 2005. Late Eocene-early Oligocene organic-walled dinoflagellate cysts from Folusz, Magura Nappe, Polish Carpathians. Acta Palaeobotanica, 45: 27-83.

Gedl, P., 2013. Eocene dinoflagellate cysts from the Popiele beds at Koniusza (Skole Nappe, Flysch Carpathians, Poland): taxonomy, biostratigraphy, and palaeoenvironmental reconstruction of a marginal marine basin. Studia Geologica Polonica, 136 : 5-197.

Golonka, J., Oszczypko, N., Ślączka, A., 2000. Late Carboniferous-Neogene geodynamic evolution and paleogeography of the Circum-Carpathian region and adjacent areas. Annales Societatis Geologorum Poloniae, 70: 107-136

Golonka, J., Gahagan, L., Krobicki, M., Marko, F., Oszczypko, N., Ślączka, A., 2006. Plate tectonic evolution and paleogeography of the circum Carpathian region. AAPG Memoir, $\mathbf{8 4}$ 11-46.

Heilmann-Clausen, C., Egger, H., 2000. The Anthering outcrop (Austria), a key-section for correlation between Tethys and Northwestern Europe near the Paleocene/Eocene boundary. GFF, 122: 69

lakovleva, A.I., Brinkhuis, H., Cavagnetto, C., 2001. Late Palaeocene-Early Eocene dinoflagellate cysts from the Turgay Strait, Kazakhstan; correlations across ancient seaways. Palaeoge ography, Palaeoclimatology, Palaeoecology, 172: 243-268.

Jan du Chęne, R., Adediran, S.A., 1984. Late Paleocene to Early Eocene dinoflagellates from Nigeria. Cahiers de Micropaléontologie, Centre National de la Recherche Scientifique, 3 : 5-38.

Jankowski, L., Ślączka, A., 2014. Objaśnienia do Szczegółowej Mapy Geologicznej Polski w skali 1:50 000 (in Polish): 1-38. Arkusz Jabłonki (1065). Państwowy Instytut GeologicznyPaństwowy Instytut Badawczy.

Jurewicz, E., Segit, T., 2018. The tectonics and stratigraphy of the transitional zone between the Pieniny Klippen Belt and Magura Nappe (Szczawnica area, Poland). Geology, Geophysics and Environment, 44: 127-144.

Kennett, J.P., Stott, L.D., 1991. Abrupt deep-sea warming, palaeoceanographic changes and benthic extinctions at the end of the Palaeocene. Nature, 353: 225-229.

Kocsis, L., Ounis, A., Baumgartner, C., Pirkenseer, C., Harding, I.C., Adatte, T., Chaabani, F., Neili, S.M., 2014. Paleocene-Eocene palaeoenvironmental conditions of the main phosphorite deposits (Chouabine Formation) in the Gafsa Basin, Tunisia. Journal of African Earth Sciences, 100: 586-597.
Kováč, M., Andreyeva-Grigorovich, A., Bajraktarević, Z., Brzobohatý, R., Filipescu, S., Fodor, L., Harzhauser, M., Nagymarosy, A., Oszczypko, N., Pavelić, D., Rögl, F., Saftić, B., Sliva, L., Studencka, B., 2007. Badenian evolution of the Central Paratethys Sea: paleogeography, climate and eustatic sea-level changes. Geologica Carpathica, 58: 579-606.

Köthe, A., 1990. Paleogene dinoflagellates from northwest Germany- biostratigraphy and palaeoenvironments. Geologisches Jahrbuch A, 118: 3-111.

Martini, E., 1971. Standard Tertiary and Quaternary calcareous nannoplankton zonation. Proceedings of the 2nd Planktonic Conference, Roma: 739-785.

Mastella, L., 1995. Tektonika jednostki przeddukielskiej (Bieszczady) - program KBN nr 600999101 (in Polish). Archiwum Wydziału Geologii Uniwersytetu Warszawskiego.

Mohamed, O., Wagreich, M., 2013. Organic-walled dinoflagellate cyst biostratigraphy of the Well Höflein 6 in the Cretaceous-Paleogene Rhenodanubian Flysch Zone (Vienna Basin, Austria). Geologica Carpathica, 64: 209-230.

Newman, J.W., Parker, P.L., Behrens, E.W., 1973. Organic carbon isotope ratios in Quaternary cores from the Gulf of Mexico. Geochimica et Cosmochimica Acta, 37: 225-238.

Nøhr-Hansen H., 2003. Dinoflagellate cyst stratigraphy of the Palaeogene strata from the Hellefisk-1, Ikermiut-1, Kangâmiut-1, Nukik-1, Nukik-2 and Qulleq-1 wells, offshore West Greenland. Marine and Petroleum Geology, 20: 987-1016.

Oboh-lkuenobe, F.E., Antolinez-Delgado, H., Awad, W.K., 2017. Dinoflagellate cysts assemblages, biostratigraphy and paleoenvironment of a Paleocene-Early Eocene sedimentary succession in the northern Niger Delta Basin: comparison with low, mid and high latitude regions. Palaeogeography, Palaeoclimatology, Palaeoecology, 481: 29-43.

Oszczypko, N., 2004. The structural position and tectonosedimentary evolution of the Polish Outer Carpathians. Przegląd Geologiczny, 52: 780-791.

Oszczypko, N., Ślączka, A., ytko, K., 2008. Tectonic subdivision of Poland: Polish Outer Carpathians and their foredeep (in Polish with English summary). Przegląd Geologiczny, 56: 927-935.

Pagani, M., Pedentchouk, N.,. Huber, M., Sluijs, A., Schouten, S., Brinkhuis, H., Sinninghe Damsté, J.S., Dickens, G.R., IODP Expedition 302 Expedition Scientists, 2006. Arctic hydrology during global warming at the Palaeocene- Eocene thermal maximum. Nature, 442: 671-675.

Poulsen, N.E., Gudmundsson, L., Hansen, J.M., Husfeldt, Y., 1990. Palynological preparation techniques, a new maceration tank-method and other modifications. Geological Survey of Denmark, Series C, 10: 1-22.

Powell, A.J., 1992. Dinoflagellate of the Tertiary System. In: A Stratigraphic Index of Dinoflagellate Cysts (ed. A.J. Powell): 156-251. British Micropalaeontological Society Publication Series, Chapman and Hall, London.

Powell, A.J., Brinkhuis, H., Bujak, J.P., 1996. Upper Paleocene-lower Eocene dinoflagellate cyst sequence biostratigraphy of southeast England. Geological Society Special Publications, 101: 145-183.

Sánchez-Pellicer, R., Masure, E., Villier, L., 2017. A new biostratigraphic correlation for Late Cretaceous-Paleocene strata of the Gulf of Guinea: evidence from dinoflagellate cysts. Comptes Rendus Geoscience, 349: 32-41.

Schouten, S., Woltering, M., Rijpstra, W.I.C., Sluijs, A., Brinkhuis, H., Sinninghe Damsté, J.S., 2007. The PaleoceneEocene carbon isotope excursion in higher plant organic matter: differential fractionation of angiosperms and conifers in the Arctic. Earth and Planetary Science Letters, 258: 581-592.

Shcherbinina, E., Gavrilov, Y., lakovleva, A., Pokrovsky, B., Golovanova, O., Aleksandrova, G., 2016. Environmental dynamics during the Paleocene-Eocene thermal maximum (PETM) in the northeastern Peri-Tethys revealed by high-resolution micropalaeontological and geochemical studies of a Caucasian key section. Palaeogeography, Palaeoclimatology, Palaeoecology, 456: 60-81. 
Sluijs, A., Brinkhuis, H., 2009. A dynamic climate and ecosystem state during the Paleocene-Eocene Thermal Maximum: inferences from dinoflagellate cyst assemblages on the New Jersey Shelf. Biogeosciences, 6: 1755-1781.

Sluijs, A., Brinkhuis, H., Schouten, S., Bohaty, S.M., John, C.M., Zachos, J.C., Reichart, G.-J., Sinninghe Damsté, J.S., Crouch, E.M., Dickens, G.R., 2007. Environmental precursors to light carbon input at the Paleocene/Eocene boundary. Nature, 450: 1218-1221.

Sluijs, A., Brinkhuis, H., Crouch, E.M., John, C.M., Handley, L., Munsterman, D., Bohaty, S.M., Zachos, J.C., Reichart, G.-J., Schouten, S., Pancost, R.D., Sinninghe Damsté, J.S., Welters, N.L.D., Lotter, A.F., Dickens, G.R., 2008. Eustatic variations during the Paleocene-Eocene greenhouse world. Paleoceanography, 23: 1-18.

Sluijs, A., Bijl, P.K., Schouten, S., Röhl, U., Reichart, G.-J, Brinkhuis, H., 2011. Southern ocean warming, sea level and hydrological change during the Paleocene-Eocene therma maximum. Climate of the Past, 7: 47-61.

Steurbaut, E., Magioncalda, R., Dupuis, C., Van Simaeys, S., Roche, E., Roche, M., 2003. Palynology, paleoenvironments, and organic carbon isotope evolution in lagoonal Paleocene-Eocene boundary settings in North Belgium. GSA Special Paper, 369: 291-317.

Stiller, M., 1977. Origin of sedimentation components in Lake Kinneret traced by their isotopic composition. In: Interaction Between Sediments and Freshwater (ed. H.L. Golterman): 57-64 Junk, The Hague.

Stover, L,E., Brinkhuis, H., Damassa, S.P., de Verteuil, L., Helby, R.J., Monteil, E., Partridge, A.D., Powell, A.J., Riding, J.B., Smelror, M., Williams, G.L., 1996. Chapter 19. Mesozoic-Tertiary dinoflagellates, acritarchs and prasinophytes. American Association of Stratigraphic Palynologists Foundation, 2: 641-750.

Ślączka, A., 1959. Stratigraphy of the Bystra scale (Middle Carpathians) (in Polish with English summary). Biuletyn Instytutu Geologicznego, 131: 203-251.

Świdziński, H., 1953. Karpaty fliszowe między Dunajcem a Sanem (in Polish). In: Regionalna Geologia Polski, 1 Karpaty, 2 Tektonika (ed. M. Ksią kiewicz): 362-422. Polskie Towarzystwo Geologiczne, Kraków.

Świdziński, H., 1958. Mapa Geologiczna Karpat Polskich 1:200,000. Część wschodnia. Prace Instytutu Geologicznego, Warszawa.

Thiry, M., Aubry, M.-P., Dupuis, C., Sinha, A., Stott, L.D., Berggren, W.A., 2006. The Sparnacian deposits of the Paris Basin: $\delta^{13} \mathrm{C}$ isotope stratigraphy. Stratigraphy, 3: 119-138.

Thomas, E., Shackleton, N.J., 1996. The Paleocene-Eocene Benthic Foraminiferal Extinction and Stable Isotope Anomalies. The Geological Society Special Publications, 101: 401-444.
Thomas, D.J., Zachos, J.C., Bralower, T.J., Thomas, E., Bohaty, S., 2002. Warming the fuel for the fire: evidence for the thermal dissociation of methane hydrate during the Paleocene-Eocene thermal maximum. Geology, 30: 1067-1070.

Tołwiński, K., 1933. Centralna depresja karpacka (in Polish). Geologia i Statystyka Naftowa Polski, 7: 362-366.

Tripati, A., Elderfield, H., 2005. Deep-sea temperature and circulation changes at the Paleocene-Eocene Thermal Maximum. Science, 308: 1894-1898.

Tyson, R.V., 1993. Palynofacies analysis. In: Applied Micropalaeontology (ed. D.J. Jenkins): 153-191. Kluwer, Dordrecht.

Westerhold, T., Röhl, U., McCarren, H.K., Zachos, J.C., 2009. Latest on the absolute age of the Paleocene-Eocene Thermal Maximum (PETM): new insights from exact stratigraphic position of key ash layers +19 and -17 . Earth Planetary Science Letters, 287: 412-419.

Williams, G.L., Bujak, J.P., 1985. Mesozoic and Cenozoic Dinoflgellates. In: Plankton Stratigraphy (eds. H.M. Bolli, J.B. Saunders and K. Petch-Nielsen): 847-964. Cambridge University Press.

Williams, G.L., Brinkhuis, H., Pearce, M.A., Fensome, R.A., Weegink, J.W., 2004. Southern Ocean and global dinoflagellate cyst events compared: index events for the Late Cretaceous-Neogene. In: Proceedings of the Ocean Drilling Program (eds. N.F. Exon, J.P. Kennett and M.J. Malone). Scientific Results Volume, 189: 1-98.

Williams, G.L., Damassa, S.P., Fensome, R.A., Guerstein, G.R., 2015. Wetzeliella and its allies - the "hole" story: a taxonomic revision of the Paleogene dinoflagellate subfamily Wetzelielloideae. Palynology, 39: 289-344.

Williams, G.L., Fensome, R.A., MacRae, R.A., 2017. DINOFLAJ3. American Association of Stratigraphic Palynologists, Data Series no. 2.

Zachos, J.C., Wara, M.J., Bohaty, S., Delaney, M.L., Petrizzo, M.R., Brill, A., Bralower, T.J., Premoli-Silva, I., 2003. A transient rise in tropical sea surface temperature during the Paleocene-Eocene Thermal Maximum. Science, 302: 1551-1554.

Zachos, J.C., McCarren, H., Murphy, B., Röhl, U., Westerhold, T., 2010. Tempo and scale of late Paleocene and early Eocene carbon isotope cycles: Implications for the origin of hyperthermals. Earth and Planetary Science Letters, 299: 242-249.

ytko, K., Zając, R., Gucik, S., Ryłko, W., Oszczypko, N., Garlicka, I., Nemčok, J., Eliáš, M., Menčik, E., Stránik, Z., 1989. Map of the Tectonic Elements of the Western Outer Carpathians and their Foreland. In: Geological Atlas of the Western Outer Carpathians and their Foreland (eds. D. Poprawa and J. Nemčok). Polish Geological Institute Warszawa, Geological Survey of Slovak Republic Bratislava, Czech Geological Survey Praha. 